\title{
Commentary: Who needs evidence when patient preference is a Class I indication?
}

\author{
Mario Gaudino, MD, ${ }^{\mathrm{a}}$ and Joanna Chikwe, $\mathrm{MD}^{\mathrm{b}, \mathrm{c}}$
}

\footnotetext{
From the ${ }^{\mathrm{a}}$ Department of Cardiothoracic Surgery, Weill Cornell Medicine, New York, NY; ${ }^{\mathrm{b}}$ Department of Surgery, The State University of New York, Stony Brook, NY; and ${ }^{\mathrm{c} D}$ Department of Cardiovascular Surgery, Mount Sinai Medical Center, New York, NY.

Disclosures: Authors have nothing to disclose with regard to commercial support.

Received for publication May 20, 2019; accepted for publication May 21, 2019; available ahead of print June 18, 2019.

Address for reprints: Mario Gaudino, MD, Department of Cardiothoracic Surgery, Weill Cornell Medicine, $525 \mathrm{E}$ 68th St, New York, NY 10065 (E-mail: mfg9004@med.cornell.edu).

J Thorac Cardiovasc Surg 2020;159:430-502

$0022-5223 / \$ 36.00$

Copyright (C) 2019 by The American Association for Thoracic Surgery

https://doi.org/10.1016/j.jtcvs.2019.05.021
}

Tam and colleagues ${ }^{1}$ use the Society of Thoracic Surgeons Adult Cardiac Surgery Database to show how far, in the absence of any supporting evidence, clinical practice has shifted. The authors explore national trends in aortic valve prosthesis choice from 2004 to 2016 and reveal the remarkable decline in the use of mechanical prostheses from 2004 (well before the approval of transcatheter aortic valve replacement) with an increase in implanted bioprosthesis size over the same period of time.

The trend toward bioprostheses has been described in single centers and registries from Europe, and the United States. ${ }^{1-5}$ Although the advantages of bioprosthesis use in older patients are well established, the switch to bioprostheses described here in much younger patients defies guideline recommendations and observational data suggesting mechanical prostheses are associated with better outcomes in adults older than age 50 years. ${ }^{5-8}$ This analysis lays to rest any illusion that the radical practice change followed transcatheter-based interventions, because the trend started years before these were available.

The superb analysis beautifully frames fundamental questions: Why are we using so many more biological valves; and, Why are we using larger ones? The second question is easier to answer. Because transcatheter valves claim the majority of patients with aortic stenosis, the growing proportion of patients with aortic regurgitation in the surgical aortic valve cohort likely explains the larger bioprosthetic surgical valves-the authors could confirm this by evaluating valve etiology.

The first question, regarding the shift to bioprosthesis use in younger patients without supporting evidence, is harder to address. Patient preference is a Class I indication for either prosthesis type, ${ }^{7,8}$ but recent data suggest that patients' involvement in valve choice is suboptimal. ${ }^{9}$ Navigating the complex balance of stroke, bleeding, and reoperation risk is challenging for patients, who commonly center

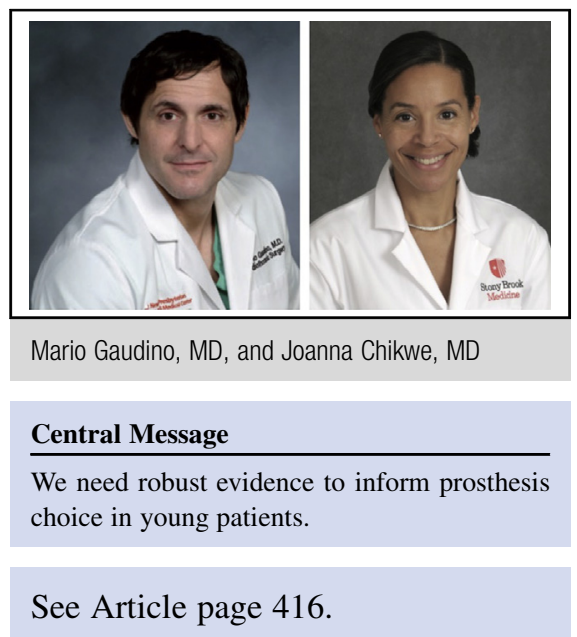

their immediate preferences around avoiding anticoagulation therapy. Surgeons seem more inclined to avoid anticoagulation and to choose a biological valve than cardiologists, ${ }^{10}$ which brings us again to this question: In the absence of clear evidence, guideline recommendations, informed patient preference, and major technical or safety advantages, should we be choosing biological valves for young patients as often as we are?

A registry analysis cannot answer this question because it contains no long-term outcome data for young patients. A randomized trial would require decades, thousands of patients, and enough surgeons with the clinical equipoise needed to randomize. Most retrospective analyses are plagued by selection bias, thanks to prior decades where only the least compliant patients with the shortest life expectancy and the poorest access to health care received a bioprosthesis. Meta-analyses of nonrandomized data simply compound the problems.

But there are important questions we can answer now. We increasingly pin young patients' hopes on transcatheter and valve-in-valve replacement-but what are the 5-year outcome data in low- and intermediate-risk transcatheter populations? Can anticoagulation therapy reduce bioprosthetic valve thrombosis and structural degeneration? Why is anticoagulation as unthinkable for some patients as stroke or open-heart surgery — do we need a better framework for these conversations? Tam and colleagues ${ }^{1}$ highlight how far our practice has moved without evidence. We owe it to our patients to find strong evidence for our next move. 


\section{References}

1. Tam DY, Rocha R, Wijeysundera HC, Austin PC, Dvir D, Fremes SE. Surgical valve selection in the era of transcatheter aortic valve replacement in the Society of Thoracic surgeons database. J Thorac Cardiovasc Surg. 2020;159:416-27.e8.

2. Fujita B, Ensminger S, Bauer T, Möllmann H, Beckmann A, Bekeredjian R, et al. Trends in practice and outcomes from 2011 to 2015 for surgical aortic valve replacement: an update from the German aortic valve registry on 42776 patients. Eur J Cardiothorac Surg. 2018;53:552-9.

3. Siregar S, de Heer F, Groenwold RH, Versteegh MI, Bekkers JA, Brinkman ES, et al. Trends and outcomes of valve surgery: 16-year results of Netherlands cardiac surgery national database. Eur J Cardiothorac Surg. 2014;46:386-97.

4. Dunning J, Gao H, Chambers J, Moat N, Murphy G, Pagano D, et al. Aortic valve surgery: marked increases in volume and significant decreases in mechanical valve use-an analysis of 41,227 patients over 5 years from the Society for Cardiothoracic Surgery in Great Britain and Ireland national database. J Thorac Cardiovasc Surg. 2011;142:776-82.e3.

5. Goldstone AB, Chiu P, Baiocchi M, Lingala B, Patrick WL, Fischbein MP, et al. Mechanical or biologic prostheses for aortic-valve and mitral-valve replacement. N Engl J Med. 2017;377:1847-57.

6. Puvimanasinghe JP, Steyerberg EW, Takkenberg JJ, Eijkemans MJ, van Herwerden LA, Bogers AJ, et al. Prognosis after aortic valve replacement with a bioprosthesis: predictions based on meta-analysis and microsimulation. Circulation. 2001;103:1535-41.

7. Nishimura RA, Otto CM, Bonow RO, Carabello BA, Erwin JP, Fleisher LA, et al. 2017 AHA/ACC focused update of the 2014 AHA/ACC guideline for the management of patients with valvular heart disease: a report of the American College of Cardiology/American Heart Association task force on clinical practice guidelines. J Am Coll Cardiol. 2017;70:252-89.

8. Falk V, Baumgartner H, Bax JJ, De Bonis M, Hamm C, Holm PJ, et al. 2017 ESC/ EACTS guidelines for the management of valvular heart disease. Eur J Cardiothorac Surg. 2017;52:616-64.

9. Korteland NM, Top D, Borsboom GJ, Roos-Hesselink JW, Bogers AJ, Takkenberg JJ. Quality of life and prosthetic aortic valve selection in nonelderly adult patients. Interact Cardiovasc Thorac Surg. 2016;22:723-8.

10. Korteland NM, Kluin J, Klautz RJ, Roos-Hesselink JW, Versteegh MI Bogers AJ, et al. Cardiologist and cardiac surgeon view on decision-making in prosthetic aortic valve selection: does profession matter? Neth Heart J. 2014; 22:336-43. 